\title{
PENURUNAN KADAR COD DAN BOD PADA LIMBAH CAIR KIMIA LABORATORIUM POLTEKKES KEMENKES BENGKULU DENGAN METODE BIOFILTER
}

\author{
Mutia Ade Fandini, Jubaidi, Sri Mulyati \\ Politeknik Kesehatan Kementerian Kesehatan Bengkulu, Kesehatan Lingkungan \\ Jalan Indragiri Nomor 03 Padang Harapan Bengkulu \\ srimulyati_2202@yahoo.co.id
}

\begin{abstract}
Laboratory waste is one of the waste in a small scope that tends contained many heavy metals and organic materials therein. The nature of the waste is very dangerous and toxic may not directly discharged into the environment. One of the sewage treatment by using the method biofilter. The purpose of this research is to reduce levels of COD and BOD effluent MoH Bengkulu polytechnic chemistry laboratory methods biofilter. Type of quasi experimental study with pre-post study design test. Waste derived from laboratory chemical waste. Measure the COD and BOD levels before and after treatment biofilter with five repetitions. Analyzed by univariate and bivariate. Given the results of research based on the analysis of univariate no reduction in COD levels by an average of 5.448\% and the percentage reduction in BOD levels decrease with the average percentage of $3.928 \%$ decline. Results of bivariate analysis test t-Test that there are differences in the levels of COD before and after treatment with 0.006 significance and there are differences in levels of BOD before and after treatment with 0.003 significance
\end{abstract}

Keywords: biofilter, Laboratory Waste

\begin{abstract}
Abstrak :Limbah laboratorium merupakan salah satu limbah dalam lingkup kecil yang cenderung terkandung banyak logam berat dan bahan organik didalamnya. Sifat limbah yang sangat berbahaya dan beracun tidak diperbolehkan langsung dibuang ke lingkungan. Salah satu pengolahan limbah yaitu dengan menggunakan metode biofilter. Tujuan penelitian ini adalah menurunkan kadar COD dan BOD limbah cair kimia laboratorium Poltekkes Kemenkes Bengkulu dengan metode biofilter. Jenis penelitian quasi experiment dengan desain penelitian pre-post test. Limbah berasal dari limbah kimia laboratorium. Mengukur kadar COD dan BOD sebelum dan sesudah proses biofilter dengan perlakuan lima kali pengulangan. Dianalisa secara univariat dan bivariat. Hasil penelitian Diketahui berdasarkan analisa univariat ada penurunan kadar COD dengan rata-rata persentase penurunan 5,448\% dan penurunan kadar BOD dengan rata-rata persentase penurunan 3,928\%. Hasil analisa bivariat uji $t$-Test bahwa ada perbedaan kadar COD sebelum dan sesudah perlakuan dengan signifikasi 0.006 dan ada perbedaan kadar BOD sebelum dan sesudah perlakuan dengan signifikasi 0.003
\end{abstract}

Kata kunci : Biofilter, Limbah Laboratorium

Pencemaran lingkungan merupakan salah satu faktor rusaknya lingkungan yang berdampak pada makhluk hidup disekitarnya. Sumber pencemaran lingkungan diantaranya berasal dari air, tanah, dan udara. Salah satu faktor pencemaran tersebut disebabkan oleh limbah yang berasal dari industri, domestik, pertanian, laboratorium dan sebagainya. Limbah adalah cairan, padatan, dan gas dalam suatu wilayah atau tempat tertentu yang mengalami penyim-pangan dari keadaan normal akibat adanya bahan-bahan kimia yang telah digunakan un-tuk berbagai kegiatan. Limbah laboratorium merupakan salah satu limbah dalam lingkup kecil yang cenderung terkandung banyak logam berat dan bahan organik didalamnya. Hal-hal tersebut dapat mencemari dan membahayakan lingkungan hidup disekitar-nya, seperti tumbuh-tumbuhan, hewan, dan manusia yang berada disekitar laboratorium tersebut (Azamia, 2012).

Laboratorium kimia Poltekkes Kemenkes Bengkulu digunakan sebagai sarana penun- 
jang praktek pembelajaran mahasiswa Jurusan Gizi, Jurusan Analis Kesehatan dan Jurusan Kesehatan Lingkungan. Praktek pembelajaran yang dilaksanakan pada laboratorium kimia Poltekkes Kemenkes Bengkulu meliputi pemeriksaan kimia air, titrasi asam basa, pemeriksaan COD, pemeriksaan BOD, uji formalin, uji boraks dan lain-lain. Dalam 1 semester pembelajaran menghasilkan total 20 liter limbah cair. Limbah cair laboratorium tidak diperbolehkan langsung dibuang ke lingkungan karena mengakibatkan pencemaran terhadap lingkungan. Hal ini karena sifat dari limbah laboratorium menurut Darmono (2012) adalah limbah bahan berbahaya dan beracun bersifat toksik dan tidak mudah terdegradasi secara biologis (nonbiodegradable) dan perlu dilakukan pengolahan khusus. Pengolahan limbah cair belum ada di Poltekkes Kemenkes Bengkulu mengakibatkan limbah hanya disimpan di dalam gerijen tertutup.

Pada penelitian Pijar (2014), kadar Chemical Oxygen Demand (COD) limbah cair laboratorium kimia Poltekkes Kemenkes Bengkulu sebesar $300 \mathrm{mg} / \mathrm{l}$. Hasil yang didapat lalu di bandingkan dengan Keputusan Menteri Negara Lingkungan Hidup No: 2 tahun 1998 tentang Pedoman Penetapan Baku Mutu Lingkungan, kadar COD yang diperbolehkan adalah $80 \mathrm{mg} / \mathrm{l}$. Pengolahan limbah cair sangat perlu dilakukan karena limbah cair yang disimpan dalam gerijen dalam jangka waktu kedepan akan terjadi penumpukan. Kadar COD dan BOD yang tinggi mengakibatkan limbah cair tidak diperbolehkan dibuang langsung ke ling-kungan harus melalui proses pengolahan. Menurut Eti (2004) limbah cair dengan kadar COD dan BOD di atas nilai ambang batas harus melalui proses sebelum dibuang ke lingkungan karena berdampak buruk terhadap lingkungan jika tetap dibuang ke lingkungan.

Limbah cair laboratorium tersusun atas senyawa kompleks di dalamnya. Menurut Endang (2009) limbah cair laboratorium tersusun senyawa komplek hasil dari berbagai jenis reaksi kimia. Campuran bahan kimia didalamnya membuat ikatan yang kuat antar senyawa kimia.
Praktek pembuangan limbah cair laboratorium ke lingkungan tanpa pengolahan yang memadai disebabkan oleh berbagai faktor, antara lain belum adanya teknik pengolahan yang efektif dengan biaya terjangkau. Beberapa laboratorium telah menerapkan praktek pengelolaan dengan cara memisahkan dan mengumpulkan limbah cair berbahaya dan beracun terpisah dari limbah cair yang tidak berbahaya. Akan tetapi, setelah terkumpul dalam jumlah banyak, masalah sering muncul berkaitan dengan cara pengolahan atau pembuangan limbah tersebut. Alternatif untuk mengirim limbah tersebut ke tempat pengolahan limbah B3 milik pihak ketiga sering menghadapi masalah prosedur dan biaya (Suprihatin dan Nastiti, 2010).

Pengolahan yang khusus diperlukan untuk mengolah limbah cair laboratorium kimia. Salah satu jenis pengolahan limbah cair adalah metode biofilter anaerob-aerob. Teknologi pengolahan air limbah biofilter dengan media sarang tawon adalah teknologi pengolahan air limbah yang murah dan handal dengan proses biofilter dengan media sarang tawon yang terbuat dari potongan pipa yang telah dirang-kai sedemikian rupa.

Dari hasil penelitian awal penulis kadar Chemical Oxygen Demand (COD) limbah cair kimia laboratorium Poltekkes Kemenkes Bengkulu sebesar $300 \mathrm{mg} / \mathrm{l}$, hasil yang didapat melebihi ambang batas yang diperbolehkan menurut Peraturan Menteri Lingkungan Hidup No. 5 tahun 2014 Tentang Baku Mutu Air Limbah kadar yang diperbolehkan sebe-sar $100 \mathrm{mg} / \mathrm{l}$. Sedangkan kadar Biological oxy-gen demand (BOD) limbah cair kimia labora-torium Poltekkes Kemenkes Bengkulu sebesar $280 \mathrm{mg} / \mathrm{l}$, hasil yang didapat melebihi ambang batas yang diperbolehkan menurut Peraturan Menteri Lingkungan Hidup No. 5 tahun 2014 tentang Baku Mutu Air Limbah sebesar $50 \mathrm{mg} / \mathrm{liter}$. Tujuan penelitian ini mengetahui penurunan kadar COD dan BOD limbah cair kimia laboratorium Poltekkes Kemenkes Bengkulu dengan metode biofilter. 


\section{BAHAN DAN CARA KERJA}

Jenis penelitian yang digunakan adalah Jenis penelitian yang digunakan dalam penelitian ini adalah "quasi-experiment" dengan desain rancangan penelitian "pre-post test". Limbah berasal dari limbah kimia laboratorium. Mengukur kadar COD dan BOD sebelum dan sesudah proses biofilter dengan perlakuan lima kali pengulangan. Dianalisa secara univariat dan bivariat

\section{HASIL}

\section{Analisis Univariat}

Analisa univariat bertujuan mendeskripsikan hasil pengukuran.

Tabel 1 Kadar COD dan BOD Sebelum dan Sesudah Pengolahan Air Limbah dengan Metode Biofilter

\begin{tabular}{ccc}
\hline Perlakuan & Kadar (mg/l) & Penurunan (\%) \\
\hline Kadar COD & & \\
Sebelum & 316,2 & $5,448 \%$ \\
Sesudah & 299,2 & \\
Kadar BOD & & \\
Sebelum & 279,6 & $3,928 \%$ \\
Sesudah & 269,6 & \\
\hline
\end{tabular}

Berdasarkan tabel 4.1 kadar COD ratarata sebelum perlakuan adalah $316,2 \mathrm{mg} / \mathrm{l}$ dan pada rata-rata sesudah perlakuan adalah 299,2 $\mathrm{mg} / \mathrm{l}$. Hasil rata-rata persentase penurunan adalah 5,448\%. Diketahui persentase penurunan tertinggi terletak pada pengulangan kelima yaitu dengan persentase 9,15\%. Kadar BOD rata-rata sebelum perlakuan adalah $279,6 \mathrm{mg} / \mathrm{l}$ dan pada rata-rata sesudah perlakuan adalah $269,6 \mathrm{mg} / \mathrm{l}$. Hasil rata-rata persentase penurunan adalah 3,928\%. Diketahui persentase penurunan tertinggi terletak pada pengulangan keempat yaitu dengan persentase 5,26\% .

\section{Analisis Bivariat}

Analisa bivariat dilakukan dengan menggunakan statistik dengan metode uji $t$ Test. HAsil pada Tabel2 didapatkan nilai mean sebelum adalah 316,2 dengan standar deviasi 26,593. Nilai mean sesudah 299,2 dengan standar deviasi 29,609. Nilai signifikasi kedua perlakuan tersebut adalah 0,006. Berarti ada perbedaan kadar COD sebelum dan sesudah proses biofilter. Didapatkan nilai mean sebelum adalah 279,6 dengan standar deviasi 4,775. Nilai mean sesudah 269,6 dengan standar deviasi 4,506. Nilai signifikasi kedua perlakuan tersebut adalah 0,003. Berarti ada perbedaan kadar BOD sebelum dan sesudah proses biofilter.

Tabel 2 Hasil Uji T-Test Kadar COD Sebelum dan Sesudah Pengolahan Air Limbah dengan Metode Biofilter

\begin{tabular}{|c|c|c|c|c|c|}
\hline Variabel & Mean & $\begin{array}{c}\text { Standar } \\
\text { Deviation }\end{array}$ & $\begin{array}{c}\text { Standar } \\
\text { Eror Mean }\end{array}$ & $\mathbf{N}$ & $\overline{\text { P Value }}$ \\
\hline \multicolumn{6}{|l|}{ Kadar COD } \\
\hline Sebelum & 316.2 & 26.593 & 11.893 & 5 & \\
\hline Sesudah & 299.2 & 29.609 & 13.242 & 5 & 0.006 \\
\hline \multicolumn{6}{|l|}{ Kadar BOD } \\
\hline Sebelum & 279.6 & 4.775 & 2.135 & 5 & 0.003 \\
\hline Sesudah & 269.6 & 4.506 & 2.015 & 5 & \\
\hline
\end{tabular}

\section{PEMBAHASAN}

Biofilter dimana mikroorganisme tumbuh dan berkembang diatas suatu media, yang dapat terbuat dari plastik, kerikil, atau sebagainya yang di dalam operasinya dapat tercelup sebagian atau seluruhnya, atau yang hanya dilewati air saja (tidak tercelup sama sekali), dengan membentuk lapisan lendir untuk melekat di atas permukaan media tersebut sehingga membentuk lapisan biofilm. Proses pengolahan air limbah dengan biofilter secara garis besar dapat dilakukan dalam kondisi aerob, anaerob atau kombinasi anaerob dan aerob. Proses aerobik dilakukan dengan kondisi adanya oksigen terlarut di dalam reaktor air limbah. Sedangkan proses kombinasi anaerob dan aerob merupakan gabungan proses anaerob dan proses aerob. Proses operasi bofilter secara anaerob digunakan untuk air limbah dengan kandungan zat organik cukup tinggi, dan dari proses ini akan dihasilkan gas methana. Jika kadar COD limbah kurang dari $4000 \mathrm{mg} / \mathrm{l}$ seharusnya limbah tersebut diolah pada kondisi anaerob (Herlambang, dkk, 2004).

Proses pengolahan air limbah dengan proses biofilter dilakukan dengan cara mengalirkan air limbah ke dalam reaktor biologis yang telah diisi dengan media penyangga untuk pengembangbiakkan mikroorganisme dengan atau tanpa aerasi. Untuk proses anaerobik dilakukan tanpa pemberian udara atau oksigen. Biofiletr yang baik adalah menggunakan prinsip biofiltrasi yang memiliki 
struktur menyerupai saringan dan tersusun dari tumpukan media penyangga yang disusun baik secara teratur maupun acak di dalam suatu biofilter. Adapun fungsi dari media penyangga yaitu sebagai tempat tumbuh dan berkembangnya bakteri yang akan melapisi permukaan media membentuk lapisan massa yang tipis (biofilm) (Herlambang dan Marsidi, 2009).

Di dalam proses pengolahan air limbah dengan proses biofilter aerobik, suplai udara dapat dilakukan dengan berbagai cara seperti aerasi samping, aerasi tengah, aerasi merata seluruh permukaan, aerasi eksternal aerasi dengan air lift pump dan aerasi dengan system mekanik. Sistem aerasi juga bergantung dari jenis media maupun efisiensi yang diharapkan (Herlambang, dkk, 2004).

Metode biofilter yang terbuat dari bahan anorganik, ringan dan mempunyai luas permukaan spesifik yang tinggi. Semakin tinggi luas permukaan spesifiknya maka jumlah mikroorganisme yang dapat melekat juga semakin banyak. Berdasarkan tabel yang telah dibahas diketahui bahwa meskipun air limbah telah diolah dengan menggunakan biofilter, hasilnya belum memenuhi standar baku mutu PermenLH No. 5 tahun 2014 tentang baku mutu air limbah. Hal ini dapat terjadi karena beberapa faktor seperti; jenis media yang digunakan, komposisi air limbah yang bersifat toksik, dan kurangnya masa tinggal air limbah dalam reaktor.

Menurut Said dan Firly (2005), zat toksik dapat menyebabkan kegagalan pada proses penguraian limbah pada proses anaerobik. Bahan-bahan kimia merupakan bahan yang berbahaya dan memiliki resiko tinggi bila tercemar ke lingkungan, karena memliki zat yang bersifat racun (toksik). Tidak hanya bahan-bahan kimia, akan tetapi dimiliki oleh logam-logam berat sehingga aliran buangan limbah laboratorium akan membahayakan lingkungan dan makhluk hidup disekitarnya bila tidak dilakukan pengolahan limbah terlebih dahulu (Eti,2004).

Waktu tinggal atau masa tinggal adalah waktu perjalanan limbah cair dalam reaktor atau lamanya proses pengolahan limbah cair tersebut. Semakin lama waktu tinggal, maka penyisishan yang terjadi akan semakin besar. Sedangkan waktu tinggal pada reaktor sangat bervariasi mulai dari satu jam hingga berharihari (Syahriar, 2013).

Proses aerob menggunakan oksigen $\left(\mathrm{O}_{2}\right)$. Dibutuhkan aerasi sesuai dengan kebutuhan yang diinginkan. Proses aerob biasanya menghasilkan biomassa dalam jumlah besar (66\%) dan menghasilkan air, gas, asam organik (34\%) (Sutapa D. AI, 2004).

Dalam proses anaerob, peruraian bahan organik dilakukan oleh mikroorganisme. Mikroorganisme tersebut dibagi dalam dua kelompok yaitu kelompok 1 yang menghidrolisa dan memfermentasi komponen organik kompleks menjadi komponen organik sederhana seperti asam asetat dan asam propionat.Kelompok bakteri ini terdiri dari bakteri anaerob dan fakultatif yang disebut pembentuk asam. Kelompok II adalah mikroorganisme yang mengubah asam organik yang dibentuk oleh kelompok I menjadi gas methane dan gas $\mathrm{CO}_{2}$. Bakteri ini disebut pembentuk methan. Beberapa kelompok bakteri anaerob dan fakultatif yang lain memanfaatkan macam-macam ion inorganik yang ada dalamlumpur seperti bakteri mereduksi ion sulfat menjadi ion sulfit dan mereduksi Nitrat menjadi nitrogen. (Sutapa D. AI, 2004).

Air limbah rumah sakit yang berasal dari buangan domistik maupun buangan limbah cair klinis umumnya mengadung senyawa pulutan organik yang cukup tinggi, dan dapat diolah dengan proses pengolahan secara biologis, sedangkan untuk air limbah rumah sakit yang berasal dari laboratorium biasanya banyak mengandung logam berat yang mana bila air limbah tersebut dialirkan ke dalam proses pengolahan secara biologis, logam berat tersebut dapat menggagu proses pengolahannya. Oleh karena itu untuk pengelolaan air limbah rumah sakit, maka air limbah yang berasal dari laboratorium dipisahkan dan ditampung, kemudian diolah secara kimiafisika, Selanjutnya air olahannya dialirkan bersama-sama dengan air limbah yang lain, dan selanjutnya diolah dengan proses pengolahan secara biologis. (Syahriar, 2013). 


\section{KESIMPULAN}

Disimpulkan bahwa rata-rata kadar COD pada limbah cair kimia laboratorium Poltekkes Kemenkes Bengkulu sebelum pengolahan air limbah dengan metode biofilter sebesar 316,2 dan sesudah pengolahan sebesar 299,2, rata-rata kadar BOD pada limbah cair kimia laboratorium Poltekkes Kemenkes Bengkulu sebelum pengolahan air limbah dengan biofilter sebesar 279,6 dan sesudah pengolahan sebesar 269,6 , terdapat perbedaan kadar COD sebelum dan sesudah pengolahan air limbah dengan metode biofilter pada limbah cair kimia laboratorium Poltekkes Kemenkes Bengkulu dengan $\mathrm{P}$ Value sebesar 0,006 , terdapat perbedaan kadar BOD sebelum dan sesudah pengolahan air limbah

\section{DAFTAR RUJUKAN}

Azamia, Mia (2012). Pengolahan Limbah Cair Laboratorium Kimia Dalam Penurunan Kadar Organik Serta Logam Berat Fe, Mn, Cr Dengan Metode Koagulasi dan Ardsorpsi. Skripsi. Universitas Indonesia.

Darmono, (2012). Logam berat suatu zat pencemar yang berbahaya. Artikel, Kompas. Indonesia.

Endang, (2009). Penanganan Limbah Laboratorium Kimia. Jurnal. Pendidikan Kimia FMIPA Universitas Negeri Yogyakarta. Yogyakarta.

Eti Rohaeti, Tri Nenny dan irmanida Batubara (2004). Pengolahan Limbah Cair dari Kegiatan Praktikum Analisis SPOT Test dengan Koagulasi Menggunakan Polialumunium Klorida. Jurnal. Departemen Kimia FMIPA-IPB Bogor. ISSN 1410-6086

Herlambang dan Marsidi (2009). Proses Denitrifikasi Dengan Sistem Biofilter Untuk Pengolahan Air Limbah Yang Mengandung Nitrat. Jurnal Teknologi. Jakarta

Pijar (2014). Penurunan Kadar COD dan Logam Berat Krom Pada Limbah Cair dengan Metode Elektrokoagulasi dan Flotasi di Laboratorium dengan metode biofilter pada limbah cair kimia laboratorium Poltekkes Kemenkes Bengkulu dengan $\mathrm{P}$ Value sebesar 0,003. Disarankan bagi institusi pendidikan/akademik untuk dapat diterapkan untuk mengolah limbah cair kimia laboratorium Poltekkes Kemenkes Bengkulu, dan dapat digunakan sebagai bahan pembelajaran pada mata kuliah PAPLC (pengolahan air dan pengolahan limbah cair, bagi peneliti lain untuk melakukan penelitian lanjutan dengan menggunakan media lain selain media sarang tawon yang terbuat dari pipa bekas menjadi biofilter agar lebih banyak menghasilkan biofilm sehingga kadar COD dan BOD terjadi penurunan sesuai dengan baku mutu yang berlaku.

Kimia Poltekkes Kemenkes Bengkulu. Karya Tulis Ilmiah. Poltekkes Kemenkes Bengkulu

Peraturan Menteri Lingkungan Hidup No. 5 Tahun 2014 tentang Baku Mutu Air Limbah.

Said dan Firly (2005). Uji Performance Biofilter Anaerobik Unggun Tetap Menggunakan Media Biofilter Sarang Tawon Untuk Pengolahan Air Limbah Rumah Potong Ayam. Kelompok Teknologi Pengelolaan Air Bersih dan Limbah Cair, Pusat Pengkajian dan Penerapan Teknologi Lingkungan, BPPT. Jurusan Kimia, Universitas Negeri Jakarta. 289-302

Suprihatin dan Nastiti (2010). Penyisihan Logam Berat dari Limbah Cair Laboratorium dengan Metode Presipitasi dan Ardsopsi. Jurnal. Institut Pertanian Bogor.

Sutapa D. AI. (2004). Lumpur Aktif : Alternatif Pengolah Limbah Cair, Jurnal Studi Pembangunan, Kemasyarakatan \& Lingkungan, No. $3 ; 25-38$.

Syahriar, Tato (2013). Penggunaan Biofilter AnaerobAerob Terhadap Limbah Cair Rumah Sakit. Jurnal Vol. 2 